Portland State University

PDXScholar

Spring 6-28-2019

\title{
Spatial Analysis of Burglary and Robbery Crime Concentration Near Mass-Transit in Portland
}

Bryce Edward Barthuly

Portland State University

Follow this and additional works at: https://pdxscholar.library.pdx.edu/open_access_etds

Part of the Criminology Commons, and the Transportation Commons

Let us know how access to this document benefits you.

\section{Recommended Citation}

Barthuly, Bryce Edward, "Spatial Analysis of Burglary and Robbery Crime Concentration Near Mass-Transit in Portland" (2019). Dissertations and Theses. Paper 5034.

https://doi.org/10.15760/etd.6910

This Thesis is brought to you for free and open access. It has been accepted for inclusion in Dissertations and Theses by an authorized administrator of PDXScholar. Please contact us if we can make this document more accessible: pdxscholar@pdx.edu. 
Spatial Analysis of Burglary and Robbery Crime Concentration

Near Mass-Transit in Portland

by

Bryce Edward Barthuly

A thesis submitted in partial fulfillment of the requirements for the degree of

Master of Science in

Criminology and Criminal Justice

Thesis

Committee:

Kathryn Wuschke

Ryan Labrecque

Debra Lindberg

Portland State University

2019 
(C) 2019 Bryce Edward Barthuly 


\begin{abstract}
The relationship between mass-transit and concentration of burglary and robbery crimes is inconsistent within the available literature in environmental criminology. A number of studies have provided evidence of crime concentration at and near mass transit locations where paths intersect, referred to as a node. These empirical studies bring in environmental criminology theory with the idea that crime is clustered, and the pattern of the concentrations is substantially influenced by how and why people travel and move in a city (Brantingham, Brantingham, \& Wong, 1991). It is suggested that public transit allows for a large proportion of the population to move around the community along a restricted number of destinations and paths; therefore, this concentration of population frames opportunities, and increases overall concentrations of crime (Sherman, Gartin, \& Buerger, 1989; Loukaitou-Sideris, 1999; Brantingham et al., 1991). Establishments and environments surrounding transit nodes may act as crime generators or attractors, as a high influx of people are drawn to the area via nearby transit services (Sherman et al., 1989; Loukaitou-Sideris, Liggett, \& Iseki, 2002; Kooi, 2003; Hart \& Miethe, 2014). More recent literature has identified contrasting results, finding that crime does not concentrate near mass transit areas (Gallison, 2016; Gallison \& Andresen, 2017; Ridgeway \& MacDonald, 2017). In some cases, transit facilities appear to act as protective nodes, with lower counts of crime occurring in and around these locales (La Vigne, 1996; Sedelmaier \& Kennedy, 2003).

Given the conflicting results of existing research about crime at and near transit nodes, this study advances work in environmental criminology by analyzing the concentration of burglary and robbery events in Portland, Oregon. Recognizing that
\end{abstract}


crime concentrations may vary depending on the level of analysis, this study explores crime concentrations at multiple levels of analysis (Brantingham, Brantingham, Vajihollahi \& Wuschke, 2009; Wuschke \& Kinney, 2018). At the macro-level, this study examines burglaries and robberies across Portland as a whole to determine whether these events concentrate around mass transit nodes, when compared to other areas of the city. The meso-level examines within the broad category of mass transit, to explore whether burglary and robbery events cluster differently around different types of mass transit. Finally, the micro scale investigates the five highest-crime transit nodes to explore how burglary and robbery events concentrate in close proximity to these important locations. This study finds that while crime concentrates at higher levels surrounding mass transit nodes within Portland, the patterns of this concentration changes as the spatial level of analysis changes. 


\section{Dedication}

I dedicate this to those who have continued to support, advise and inspire me to pursue and achieve great opportunities and make a difference within my community and the field of criminal justice. 


\section{Acknowledgments}

This thesis was made possible by the full dedication and support of my adviser, Dr. Kathryn Wuschke, and committee, Dr. Ryan Labrecque and Dr. Debra Lindberg at Portland State University. To my family, Bruce, Cynthia and Zion Barthuly, to my friend, Matt Prosser, professors, Daniel Couch and Dr. Misty Weitzel, and to my colleagues at the Portland Police Bureau, who model the necessary bridge between academia and policing.

Thank you. 
Table of Contents

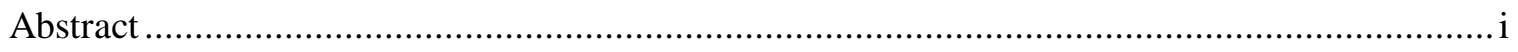

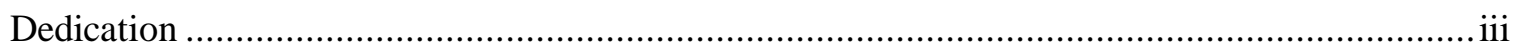

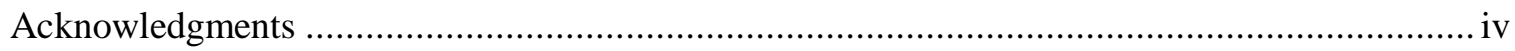

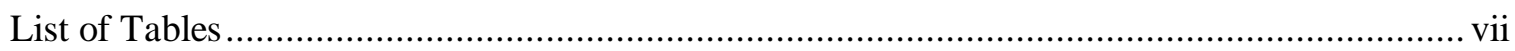

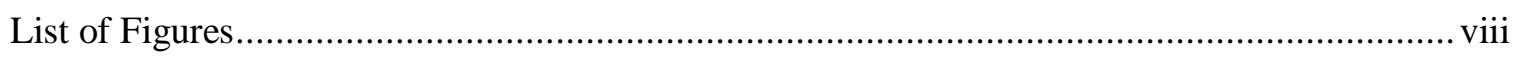

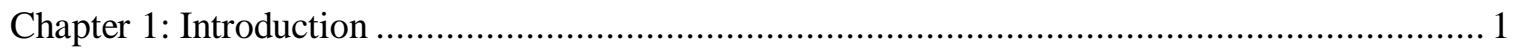

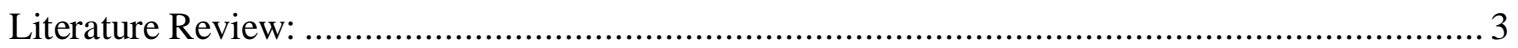

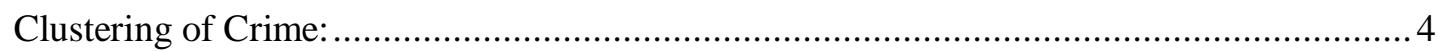

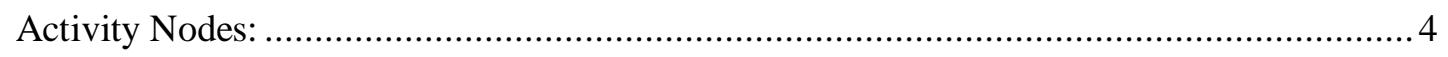

Examining the Concentration of Crime Near Mass-Transit Nodes:...................................... 6

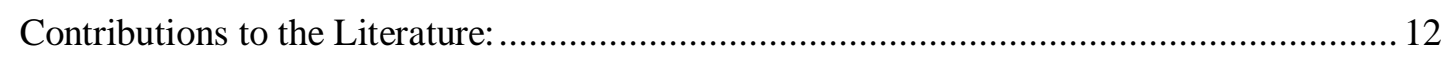

Chapter 2: Research Questions, Data and Methodology ..................................................... 14

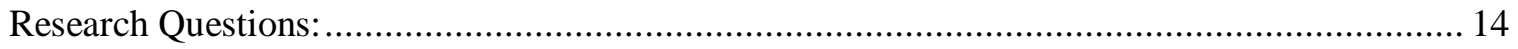

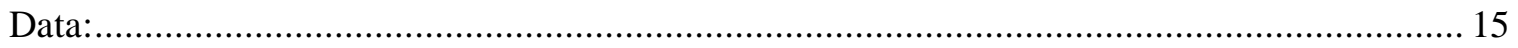

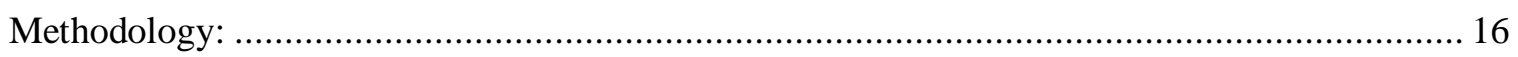

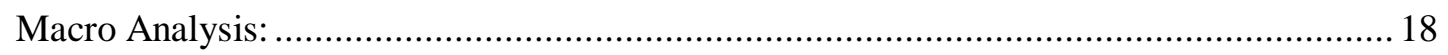

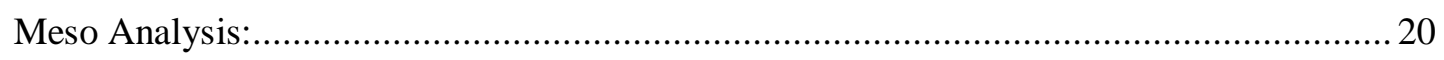

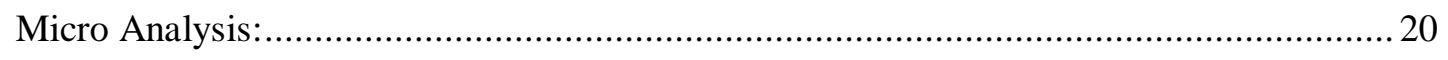

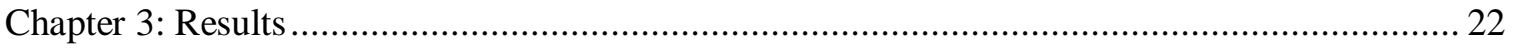

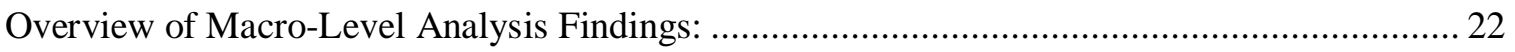

Do Burglary Crimes Concentrate Near Mass-Transit?.......................................................... 22

Do Robbery Crimes Concentrate Near Mass-Transit? ......................................................... 23

Overview of Meso-Level Analysis Findings for Burglary:.................................................... 23

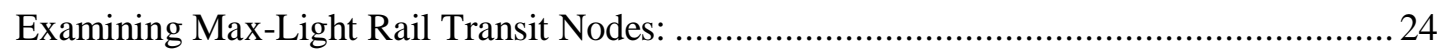

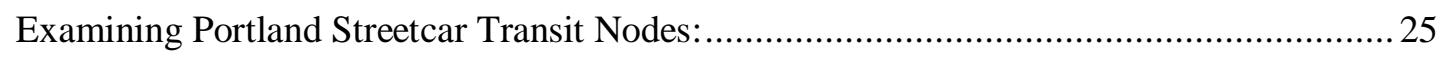

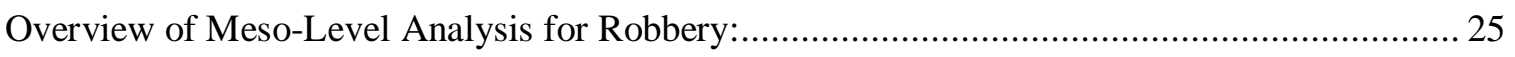

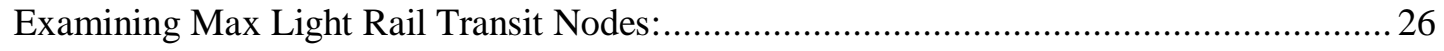

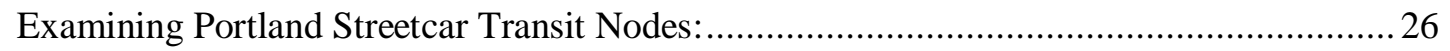

Overview of Micro-Level Analysis Findings for Burglary Crime: .......................................... 27

Examining the Spatial Dispersion of Burglaries at Different Spatial Intervals: .................. 28

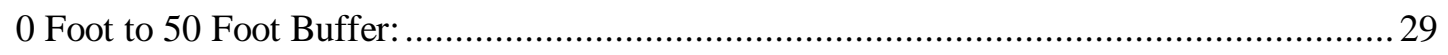




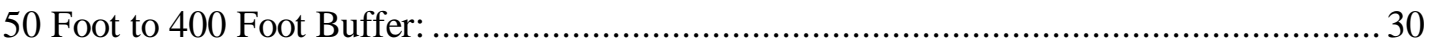

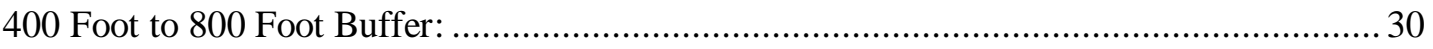

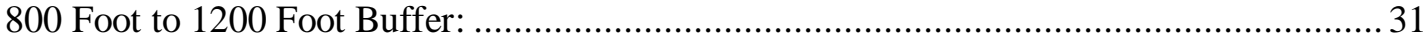

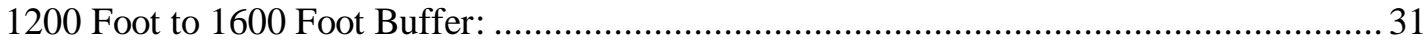

Overview of Micro-Level Analysis Findings for Robbery Crime: ............................................ 32

Examining the Spatial Dispersion of Robberies at Different Spatial-Intervals: ................... 33

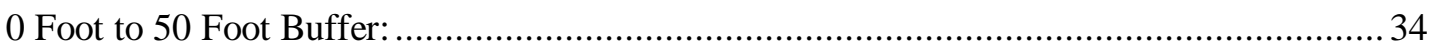

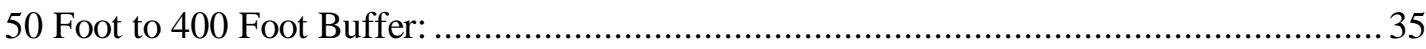

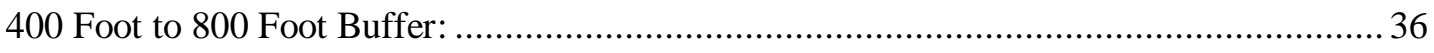

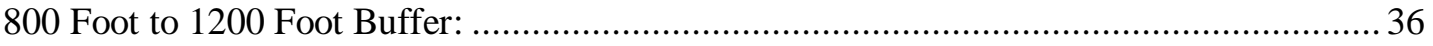

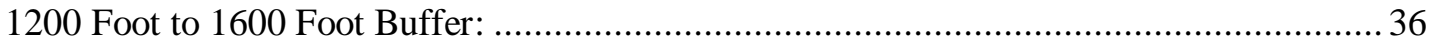

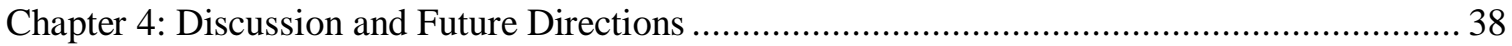

Recommendation from Literature for Conducting of a Macro-Level Analysis: ......................... 39

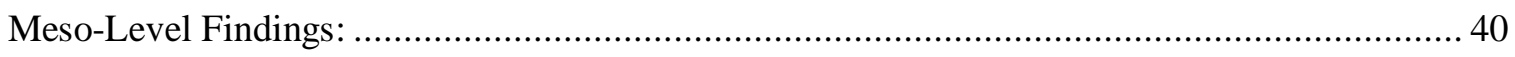

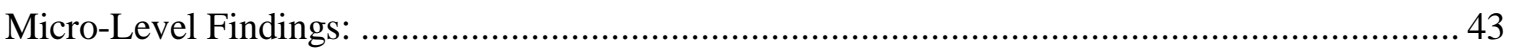

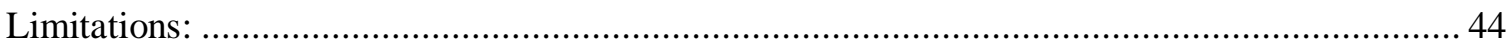

Recommendation for Future Research: ........................................................................ 46

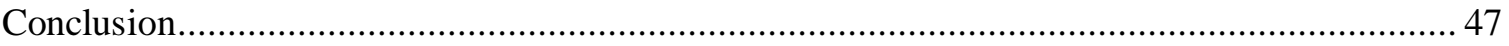

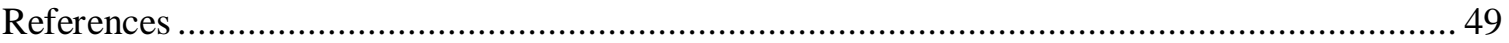




\section{List of Tables}

Descriptions $\quad$ Page

Table 1: $\quad$ Type of Crime by Area and Events with Location Quotient

22

Table 2: $\quad$ Meso-Analysis of Burglary by Type of Transit Node

Table 3: $\quad$ Meso-Analysis of Robbery by Type of Transit Node

Table 4:

Micro-Analysis of Transit Nodes with Highest

Concentration of Burglary Events

Table 5: $\quad$ LQ Values by Transit Node and Buffer Area

For Burglaries

Table 6: $\quad$ Micro Analysis of Transit Nodes with Highest

Concentration of Robbery Events

Table 7: $\quad$ LQ Values by Transit Node and Buffer Area

34

For Robberies 


\section{List of Figures}

Descriptions $\quad$ Page

Figure 1:

Transit Nodes with $400 \mathrm{ft}$. Buffers

19

Figure 2:

Examined Buffer Areas

21 


\section{Chapter 1: Introduction}

The 21st Century has brought an increase in access to public transportation, along with a corresponding debate about public safety concerns associated with such access (Trimet Annual Report, 2018). This has encouraged empirical review of the security, sustainability and stationing of mass-transit services in the United States. In the Pacific Northwest, Portland contains multiple modes of mass transportation, used by an estimated 242,019 riders per average weekend (Trimet, 2018). Given the predominance of mass transit usage within the Portland area, this locale forms an ideal site to continue to build upon existing research exploring crime concentration in proximity to transit nodes. This research explores how two crime types, robbery and burglary, concentrate in proximity to mass transit nodes in Portland, at multiple scales of aggregation.

Recent public debate regarding crime, disorder and fear associated with transit ridership in Portland, as reported by local news outlets, has encouraged an outside empirical review of crime in and around transit stations (Redden, 2017; Altstadt, 2018). Despite the recent national and local media coverage of violent attacks, and the perceived increases of property and personal crime against transit riders in Portland, the 2017 Trimet yearly crime statistical report is unable to determine whether current crime occurring at or near the city's Trimet services has increased, decreased or remained constant (Trimet Annual Report, 2018; Njus, 2017; Altstadt, 2018). This is due to the recent reporting system change to the National Incident-Based Reporting System (NIBRS); a commonly used reporting database in other governing agencies such as the 
Portland Police Bureau. Due to the NIBRS system counting and tracking all crime occurrences within each criminal event, this data is unable to be compared to data collected within previous years, which recorded only the most severe offense (Altstadt, 2018).

While other major urban cities in the United States have conducted spatial and temporal analyses of crime in and around major transit nodes, there is a shortage of such research in Portland. Presently, administrators of public transportation services such as Trimet believe the "overall picture is good," despite the inability to support such conclusions with measurable data, noting there are few crime occurrences per rider who use transit services within Portland (Durmont, 2018). Such executives have primarily focused these statements on crime occurring on public transit and platforms.

With transportation executives remaining open to public debate and relationshipbuilding with its transportation users and the Portland community, there have been multiple collaborative meetings to discuss societal issues related to crime and fear on public transportation in Portland (Redden, 2018; Altstadt, 2018). This has resulted in increased security allocation and funding toward security technology to reduce crime, disorder and fear on public transportation services in the city. This study aims to provide further empirical analysis regarding crime in proximity to major transit nodes, serving to aid in resource allocation and public understanding about crime concentrations in the Portland area. This research study extends existing conversations to explore how transportation nodes and station ridership may influence crime within the surrounding environment. 


\section{Literature Review:}

Existing literature considering crime in proximity to transit nodes frequently explores these concentrations from a pattern theory lens (Brantingham et al., 1991; Brantingham, Brantingham, \& Andresen, 2016; Eck \& Weisburd, 2015; Brantingham \& Brantingham, 1993). In such articles, transit nodes are often classified as crime generators or attractors (Brantingham \& Brantingham, 1995). Crime generators are locations that have high volumes of crime because they draw large numbers of people for non-crime reasons (Brantingham \& Brantingham, 1995). In contrast, crime attractors are locations that attract motivated offenders due to the known opportunity for criminal engagement (Brantingham \& Brantingham, 1995). These locations can include bars, drug markets and prostitution zones. Crime attractors can be thought of as luring motivated offenders to the location due to a known opportunity for crime (Frank et al., 2011).

When considering whether mass transit nodes can be classified as crime attractors or generators, one must first define what mass transit nodes are. Empirical research by Brantingham and Brantingham (1995) has identified a mass transportation node as a location where numerous variations of transit modes or travel paths intersect or converge. A second perspective of the term is provided by Kinney, Brantingham, Wuschke, Kirk and Brantingham (2008), who identify such locations as important, shared activity nodes, which act as points of convergence for large numbers of people. These points, therefore, shape both activity patterns, and crime patterns within urban areas. Mass transit nodes can become crime generators as they attract a large volume of people at one location, which increases the potential opportunities for crime to occur (Brantingham \& 
Brantingham, 1995). Examples of a mass-transit location are bus interchanges, largescale 'park and ride' lots, and transit system stops.

\section{Clustering of Crime:}

Previous empirical research suggested that few crime hot spots produce the majority of calls to law enforcement (Sherman et al., 1989). Specifically, Sherman et al. (1989) found that approximately 50 percent of all police service calls concentrated to three percent of geographic areas. In 2014, Hart and Miethe (2014) analyzed this finding by examined the specific crime types that produced the most police calls. The authors found street robberies to be highly clustered. This crime type had a high correlation with a public bus stop, which was found to be more likely, than any other activity node, to be located adjacent to a robbery event (Hart \& Miethe, 2014). Hart and Miethe (2014) conclude that the that "the risk of robbery victimization is strongly dependent on the presence or absence of a bus stop in conjunction with certain combinations of other types of activity nodes that also serve as crime generators and/or attractors" (189).

\section{Activity Nodes:}

Recent analyses of major activity nodes have typically focused on examining the land use types associated with concentration of urban crime. At the macro-level, Kinney, et al. (2008) examined crime events as they relate to broad land use types such as commercial, residential, and civic/institutional classifications. At the macro level, the authors examined violent and property crimes at the broad land use category, finding disproportionate concentrations of motor vehicle and assault crimes "on a relatively 
limited number of specific land-use types characterized by high activity functions" (Kinney et al., 2008, 11). At the meso-level, the authors explored crime concentrations within each broad land use category, finding the specific sub-types of land use that are most associated with crime within the study area. Findings suggested commercial establishments, followed by residential and recreational land uses are associated with a high proportion of assaults and motor vehicle thefts within the study site (Kinney et al., 2008). In contrast, transportation and industrial land uses are associated with a small percentage of the total assaults and motor vehicle thefts. At the micro-scale, the authors investigated crime at the address-level, identifying single locations associated with the highest counts of crime. In this study, shopping malls, multi-family apartment blocks, schools and universities contributed to a large proportion of the events within this urban area (Kinney et al., 2008).

Hart and Miethe (2014) followed a similar analytical approach, with findings suggesting specific types of nodes near mass-transportation are highly correlated to street robbery crime, and act as crime facilitators. These activity nodes can include gas stations, fast food, adult video stores, liquor outlets and pubs, and pawn shops. These findings support earlier research conducted by Sherman et al. (1989), who identified some similar activity nodes such as bus depots to be related to the concentration of robbery, as well as bars, liquor stores and parks, homeless shelters, malls, adult bookstores, hotels, convenience stores, and restaurants. When examining the concentration of crime near different activity nodes, Sherman, et al. (1989) found crime increases if a major transportation node was present in the immediate environment, thus providing access to such establishments. 
These authors, along with other criminologists, have suggested that public transportation frames opportunities for criminal acts, due to moving a large proportion of a high-risk population around the community with a restricted number of destinations and paths (Loukaitou-Sideris, 1999; Brantingham et al., 1991). Establishments that are located near mass-transportation stations and routes may be at higher risk of burglary and robbery crime. Specifically, blocks that have a crime generator or attractor such as a transportation station inside of their boundaries were found to have the highest count of robberies (Bernasco \& Block, 2011). Blocks that do not have a crime attractor or generator but are adjacent to a block that does has one, have fewer counts of robberies. However, the lowest count of robberies were found in blocks without a crime attractor, or generator, and are not geographically adjacent to a blocks that have either.

\section{Examining the Concentration of Crime Near Mass-Transit Nodes:}

In a review of available literature, Brantingham et al. (2016) found crime is not randomly distributed in space or time. Instead, crime is clustered, and the pattern of the concentration is substantially influenced by how and why people travel and move in a city. This suggests "there will be concentrations of overlapping activity nodes and within those nodes, some situations that become crime generators and some that are crime attractors" (Brantingham et al., 2016, 112). Smith and Clark (2000) and Brantingham et al. (1991) identify transit hubs and stations as potential crime generators and attractors which can shape the patterns of crime in an urban environment as they facilitate the clustering people together at a fixed location within a restricted geographic area. Research by Block and Davis (1996), Loukaitou-Sideris et al. (2002) and Newton, 
Partridge and Gill (2014) present findings that crime events tend to concentrate around such locales.

Specifically, Block and Davis (1996) found evidence of an increased risk of crime and attraction of many potential offenders and targets to semi-public and public spaces, as well as legal and illegal businesses around transit nodes. In their examination of the spatial distribution of robbery events from 1993 to 1994, they examined the concentration of street robberies near rapid mass transit nodes in two Chicago districts (Block \& Davis, 1996). Using a GeoArchive database, Block and Davis (1996) analyzed address-level information from community and law enforcement, a data set excluding commercial robberies and robberies occurring inside a transit station or on a transit service. Findings revealed 39 percent of robberies to occur within a 1,000 foot geographic area surrounding a rapid transit node (Block \& Davis, 1996). It was presumed that the volume of street robbery "was greatest during periods when fewer, and perhaps less coherent, targets and observers were likely to have been present” (Block \& Davis, 1996, 251). As a result, the amount of street robberies "peaked a short distance away from the station, where enough potential targets would still have been on the street but guardianship would have declined" (Block \& Davis, 1996, 251).

Loukaitou-Sideris et al. (2002) examined the relationship between the incidence of crime and light rail transit nodes in Los Angeles. Using a mixed methods approach, the Green Line was examined to study a relationship between the spatial distribution of crime and variation of land use characteristics, surrounding environmental attributes and sociodemographic traits. The Green Line is a 19.6 mile light-rail transit line used by an estimated 26,984 riders from Norwalk to El Segundo in Los Angeles County. Using 
crime data obtained from the Lost Angeles Transit Services Bureau, as well as demographic and ridership data, the study conducted a systematic field observation linking the variation of land uses and establishments, as well as sociodemographic and environmental attributes to each of the 14 transit platform (Loukaitou-Sideris et al., 2002, 141). Findings of this study revealed specific transit stations suffered from more crime when compared to other transit stops on the Green Line. Specifically, stations with more ridership were found to concentrate a higher amount of serious crime. Additionally, crimes against persons were found to "happen primarily at the station platform." (Loukaitou-Sideris et al., 2002, 146).

Continuing in this area, Newton et al. (2014) considered transit stations as risky facilities. The scope of the project was to measure mass-transit system called the $L U$, which has more than one million users per year in London (Newton et al, 2014). The authors examined the relationship between the distribution of theft below and above ground at $L U$ transit stations. Findings of this study revealed that the distribution of theft "is concentrated at a small proportion of stations and during peak travel hours" (Newton et al., 2014, 12). Specifically, it was estimated that approximately 50 percent of all theft occurred at 20 percent of the transit stations (Newton et al., 2014). Furthermore, it was found that 75 percent of the risk for theft occurred at 40 percent of the transit nodes (Newton et al., 2014). The authors recommend further examinations of the spatialinterplay of transit nodes within the immediate environment, specifically, assessing the land features situated around transit nodes that might influence the opportunity for theft (Newton et al., 2014). 
While a range of studies exist to emphasize the criminogenic nature of transit nodes, other work, such as that of Ridgeway and Macdonald (2017), has demonstrated contrasting findings. In their analysis of reported crime near Los Angeles transportation rail stations between 1988 and 2014, the authors found rail transportation may generate no major overall consequence for patterns of crime at the neighborhood level (Ridgeway \& Macdonald, 2017). The authors call for further empirical research to examine other cities at a micro-level unit of analysis, such as the street. They also state that additional consideration should be given to specific land-use characteristics which generate foot traffic (Ridgeway \& Macdonald, 2017).

Further studies concur with Ridgeway and Macdonald, finding less concentration of crime in areas surrounding transit nodes. Gallison (2016) explored whether the expansion of mass transportation services in Vancouver, B.C generated an increased amount of crime. The author examined crime events in, and around, the Canada Line, an addition to the Vancouver SkyTrain, using a time-series regression. The analysis found reported crime counts had decreased, since the expansion of the mass transportation service.

In Gallison and Andresen's 2017 study, the relationship between public transit and crime was further examined. They examined whether motor vehicle thefts, robbery and commercial burglaries concentrated around O-Train transit stations in Ottawa, Ontario. The authors found that O-train stations did produce increases in motor vehicle theft but did not increase commercial burglary or robbery crime. These findings emphasize the significance of examining the criminal implications of mass public transportation and the need for scanning and analysis in planning for response, and 
assessment, regarding how nodes may become generators and attractors in an environment (Gallison \& Andresen, 2017). Other research, such as Clark and Belanger (1996) and La Vigne (1997), have found secure and well-designed transit hubs to shield themselves from surrounding high risks and crime occurring in the outside environment. Clark and Belanger (1996) examined Angel's (1968) hypothesis that street level robberies are most likely to occur at a moderate level of pedestrian traffic, when compared to lower or higher levels. They looked at the distribution of 1,492 robberies recorded at the 206 subway stations in New York between August 1992 and January 1995. Using a log-linear distribution model, Clark and Belanger (1996) found rates of robbery and ridership to have an inverse relationship. Robbery was found to be highest at subway nodes with the lowest levels of ridership. Additional findings, using the rate of robbery recorded by the New York City Police Department in 1992, revealed a substantial variation in rates of robbery crime per station within each of the analyzed precincts in New York (Clark \& Belanger, 1996). Findings present an opportunity for further research in describing how the level of ridership and geographic placement of a transit facility may shield and, therefore, reduce the rate of robbery crime, when compared with other transit nodes, their level of ridership, and placement in the environment.

A similar study by La Vigne (1996) examined the metro subway system in Washington D.C., which at the time of the study, was found since its introduction in 1976 to have experienced a lower than expected rate of crime compared to other cities such as Atlanta, Chicago and Boston. Compared with other mass transit services, La Vigne (1996) examined the deterrence of crime by the transportation service due to the 
combination of management practices, design characteristics, maintenance policies and crime prevention efforts. Findings of this study revealed the uniformity of the metro stations in the design, maintenance, and "opportunity reducing characteristics," such as adequate lighting, access and control, and Crime Prevention through Environmental Design (CPTED) implementations act as environmental safeguards against the increased crime rates above ground in the community (La Vigne, 1996). As a result, enhanced measures of crime prevention taken at each of the metro stations were presumed to be deterring potential motivations for crime when compared with the less safeguarded environment above ground.

Sedelmaier and Kennedy (2003) found the incorporation of a transit station did not precisely correlate to an increased rate of crime in a geographic area. While examining the incorporation of a new public light rail transit system and the potential impact on crime patterns at the neighborhood level of analysis, Sedelmaier and Kennedy (2003) found the introduction of a light rail transit station to have a minimal impact on crime patterns. In addition, Sedelmaier and Kennedy (2003) found the average amount of police service calls decreased or remained the same following the introduction of the mass transit service. If a call for service was recorded, it was typically found to concentrate significantly distant from the location of the transit station (Sedelmaier \& Kennedy, 2003). They recommend of this article the need for continued examination of the relationship between transit and crime in order to further development and maintenance of transit by criminologists, transit planners and law enforcement in U.S cities (Sedelmaier \& Kennedy, 2003). 
Final consideration of how transit stations are not exclusively correlated with increased rates of crime include $\mathrm{Vu}$ (2009), who indicated that if a disproportionate number of stations accounted for a significant portion of crime and are considered risky facilities, then there will be several stations which experience relatively few incidents of crime . In addition, Bernasco and Block (2011) reported that, although, transit nodes increased the access to a geographic area, they were not sufficient enough to be the only increase for the risk of crime within a geographic area. The literature suggests crime levels vary for different parts of a transit system and these may be correlated to the characteristics of the neighborhood (Richards \& Hoel 1980; DeGeneste \& Sullivan 1994).

\section{Contributions to the Literature:}

Given the reviewed literature, the goal of this study is to consider how crime events concentrate near mass-transit nodes in a densely populated urban area. Given the predominance of mass-transit usage in Portland, this study allows for an exclusive assessment and continuation of the literature regarding whether crime concentrates near mass-transit in a previously unexamined densely populated area. This research study explores crime patterns near mass-transit at multiple levels of analysis within Portland, Oregon. This research adds to the conversation regarding whether burglary and robbery crime concentrates near mass-transit nodes and specifically, draw comparisons about concentrations across type of mass-transportation. In addition, this study has the potential to serve as an empirical resource to stakeholders in Portland such as the Portland Police Bureau and Trimet to contribute to recent public debate regarding crime, disorder and 
fear associated with transit ridership in Portland. This study serves to aid in resource allocation and public understanding about crime concentrations at different levels of analysis in the Portland area. 


\section{Chapter 2: Research Questions, Data and Methodology}

To continue the conversation in exploring how burglary and robbery events concentrate at, and nearm mass-transit nodes in Portland, this study examines the concentration of crime events at the macro, meso and micro level of analysis. The following section considers three questions at each level of analysis to determine the degree to which burglary and robbery crime events concentrate near mass-transit nodes, at specific types of major transit nodes, and individual stations. This chapter reviews the crime and transit data used to conduct the analysis in Portland, and introduces the methodological approaches used to analyze the concentration of crime at, and near, activity nodes.

\section{Research Questions:}

At the macro-level, this research explores whether two crime categories, burglary and robbery, concentrate in the areas immediately surrounding transit nodes within Portland, Oregon. At the meso-level, this research explores within the categories of masstransportation, to identify whether the type of mass transit may impact crime at and nearby the locale. At the micro-level, this research explores crime concentrations at and around specific, high-crime transit nodes to investigate whether and how the micro-scale patterns of crime differ from station to station. 
Data:

This study analyzes Portland Police Bureau crime event data to explore the spatial patterning of recorded crime events in the city, occurring between May 2015 and August 2018. The analysis incorporates 13,645 counts of burglary crime and 3,368 counts of robbery occurring between May 2015 and August 2018. The open-source data set is individual-level and includes crime type, as well as latitude and longitude data coordinates (Portland Police Bureau, 2019). According to the Portland Police Bureau database, robbery crime is defined as "to take or attempt to take anything of value from the control, custody, or care of another person by force, threat of force, or by putting the victim in fear of immediate harm” (Portland Police Crime Definitions, 2019, 1).

Burglaries are defined as "the unlawful entry into a building or other structure with the intent to commit a felony or a theft” (Portland Police Crime Definitions, 2019, 1). Reported crime events were imported into ESRI's ArcGIS 10.5 for spatial analysis, where events located outside of the Portland city limits were excluded from the analysis, resulting in 3,068 robbery events and 13,305 burglary events included in this analysis.

Max light rail and streetcar transit nodes within the Portland area were provided by Oregon Metro RLIS (Oregon Metro RLIS, 2019). The database is managed by the Metro Data Resource Center and was originally published in 1990 with the most recent update being on September $8^{\text {th }}, 2015$ (Oregon Metro RLIS, 2015). This dataset includes information detailing major transit stations, including light rail (referred to herein as the Max Line) and Streetcar stops. The shape file included 180 total transit nodes, including 40 transit stations outside of Portland city limits, a part of the Trimet light rail services. 
The 40 transit stops were excluded from the study in order to focus on the 70 Max and 70 Streetcar transit nodes located within Portland city limits.

\section{Methodology:}

The research includes a spatial analysis of robbery and burglary events surrounding transit stations, examined at the macro, meso and micro level. At each level, location quotients (LQs) are used to identify and measure crime concentration at transit sites. According to Groff and McCord (2012), LQs are "ratios which compare the characteristics of a sub-area under study to that of the larger, surrounding region" (Groff \& McCord, 2012, 9). The quotients are calculated for both burglary and robbery offenses by calculating a ratio of the count $\left(\mathrm{c}_{\mathrm{i}}\right)$ of robberies or burglaries within a set buffer distance from transit nodes, divided by the area $\left(a_{i}\right)$ within the buffer distance from the node. The value forms the numerator of the LQ equation, which is then divided by the count $\left(c_{r}\right)$ of robberies or burglaries in all of Portland, divided by the area $\left(a_{r}\right)$ of all of Portland. The metric calculates the crime per area in a sub-unit of analysis and comparing this to the crime per area across the entire city (McCord \& Ratcliffe, 2007, 49). This is frequently calculated as:

$$
\mathrm{LQ}=\frac{c_{i} / a_{i}}{c_{r} / a_{r}}
$$

The calculated LQs produce a value greater than 0 , which provides a measure of crime concentration. Values less than one indicate that crime is less concentrated within the sub-area than compared to the city as a whole. Values near one indicate that concentration within the sub-area is comparable to the city. Values higher than one 
indicate higher than anticipated concentration. While there is debate about the appropriate cut-off value to indicate a considerable or meaningful level of concentration, many recent studies indicated values of 1.6 or greater meet this threshold. More stringent studies have used a value of 2.0 to indicate meaningful concentration (Groff, 2011). At a LQ of 2.0, the density of crimes, within the study area is twice the density found in the city as a whole. A LQs greater than 2.0 suggests that the analyzed location has a probability of promoting the observed occurrences of crime within the studied environment (Groff \& McCord, 2012, 10). When LQs fall below a 2.0 rating, previous studies have interpreted values less than 0.9 as lower than expected within the given area; values greater than 0.9 and less than 1.1 as within the normal range for the given area; values ranging from 1.1 to 1.9 as high (Yhu, Zhu, Ye, \& Guo, 2017). Guided by this research, this study uses 2.0 as the cutoff to indicate a considerable concentration of crime.

LQs have been utilized in similar spatial analysis research such as by McCord and Ratcliffe (2007) in the examination of a micro-level spatial analysis of drug markets in Philadelphia, Pennsylvania (McCord \& Ratcliffe, 2007). Their research examined a similar transportation node with a subway station which was measured at a 400 foot, 400800 foot, 800-1200 foot, and 1200-1600 foot buffer (McCord \& Ratcliffe, 2007, 50). Calculated results of the LQs indicated drug arrests clustered within 400 foot of subway stations. However, the clustering of drug arrests near subway stations decreased as the spatial buffer spread further out into the immediate environment.

Another similar research study that incorporated LQs was Groff and McCord (2012), who examined the role of parks as crime generators at the neighborhood-level. Their hypothesis was that as the distance from the examined park increased, the 
concentration of crime would decrease. Their spatial-analysis examined parks and the surround street segments within a 50 foot, 400 foot, 800 foot, and 1200 foot buffer. Their analysis found the concentration of property, violent and disorder crime to be more clustered around and in parks when compared to Philadelphia, as a whole (Groff \& McCord, 2012). As the distance increased from the examined park, however, these concentrations were found to significantly decrease in the 400 foot buffer, rise in the 400$800 \mathrm{ft}$ buffer and then decrease to an even lower concentration at the 800-1200 foot buffer (Groff \& McCord, 2012, 11).

\section{Macro Analysis:}

This study begins by examining burglary and robbery counts at the macro level. I analyze burglary and robbery crimes within Portland, as a whole, and compare these with the concentrations immediately surrounding major transit nodes. To conduct this analysis, I create spatial buffers surrounding identified major transit nodes. These buffers are created at 400 feet; a distance used within existing literature (McCord \& Ratcliffe, 2007). This phase of analysis uses ArcGIS 10.5 to spatially join the count of both burglary and robbery events to the buffer area files, which counts the number of each type of events occurring within 400 feet of transit nodes. ArcGIS further enables the calculation of the land area contained within the buffers, in comparison with all events and the area of the city. The inputs allow for the calculation of the LQ measurement, quantifying concentration of specific crime events within close spatial proximity to the major transit nodes, Figure 1, below, illustrates the location and size of the 400 foot transit buffers. The map reviews the two types of major transit nodes included in the study (Max and 
Streetcar stops) and the location of the 400 foot buffers situated around each of the transit nodes. The figure includes the Willamette River and all Portland neighborhoods to provide visual context in relationship to the geography of Portland.

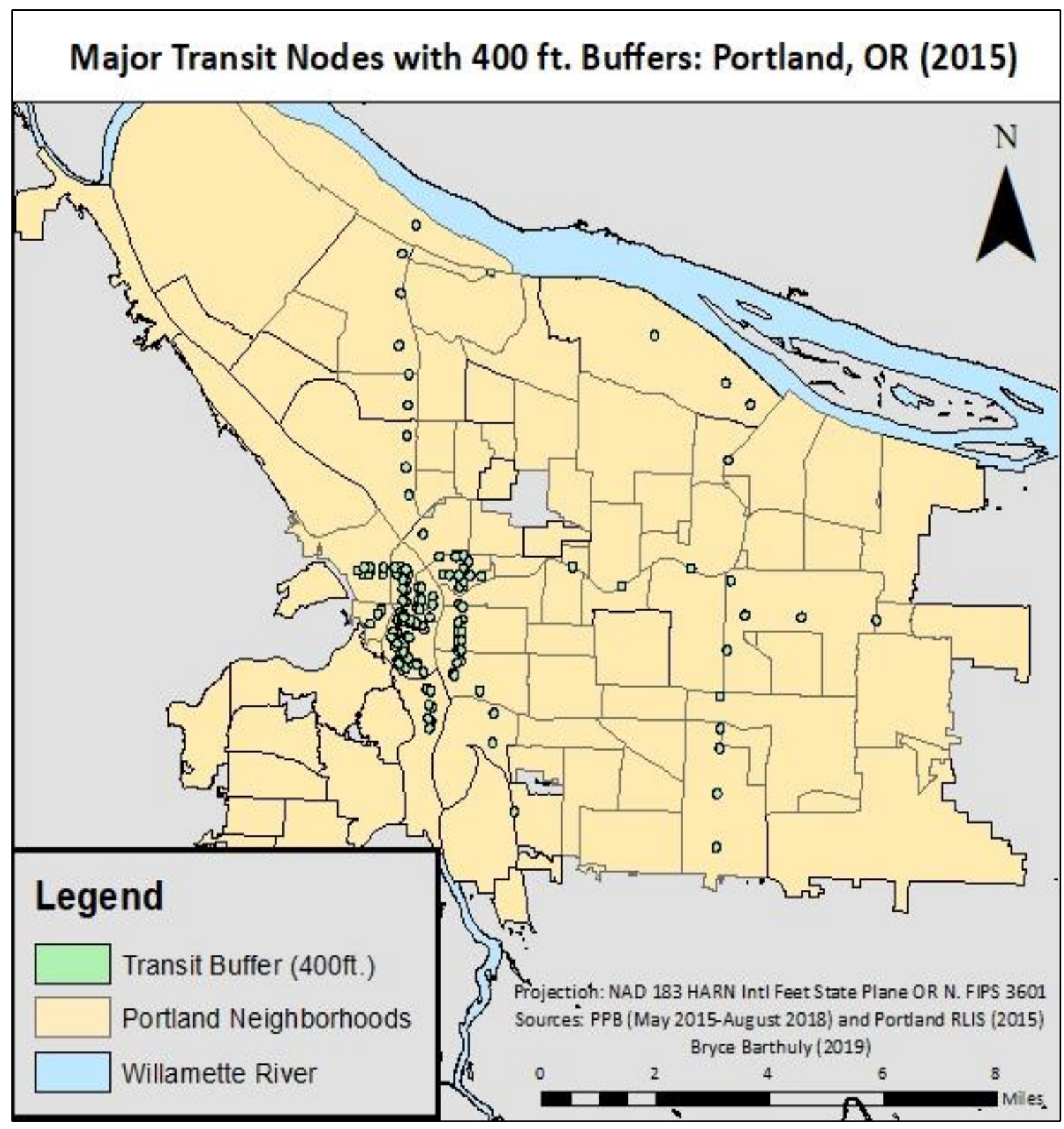

Figure 1: All Max Light Rail and Portland Streetcar Nodes are presented. The map includes Portland Neighborhoods and the Willamette River to provide a spatial-layout indicating the transit node locations. 


\section{Meso Analysis:}

In the event a crime category is found to concentrate around major transit nodes within Portland, the meso and micro analysis further explores how transit relates to the local spatial patterning of this crime type. At the meso-level of analysis, I explore how crime events concentrate around the specific transit sub-types including Trimet light rail, and the Portland Streetcar. LQs are used to identify differences in concentration surrounding each category of mass transit.

\section{Micro Analysis:}

At the micro-level, each transit node is individually analyzed to explore crime concentrations in the area nearby. Individual stations reporting the highest concentrations of crime nearby are further analyzed at a variety of distances, in an effort to better understand the local spatial variations in crime concentration around these high-crime nodes. This micro-level analysis requires a series of spatial buffers, extending outward from the initial transit station. These buffer distances follow those originally used in McCord and Ratcliffe (2007), who propose a 0-400 foot, 400-800 foot, 800-1200 foot, and 1200-1600 foot buffer around the examined location (see Figure 2). In addition, this study further incorporates the methodology of Groff and McCord (2012) who propose a 0-50 foot buffer to explore the spatial-dispersion of crime events within the microgeographic area immediately surrounding the station itself (see Figure 2). 


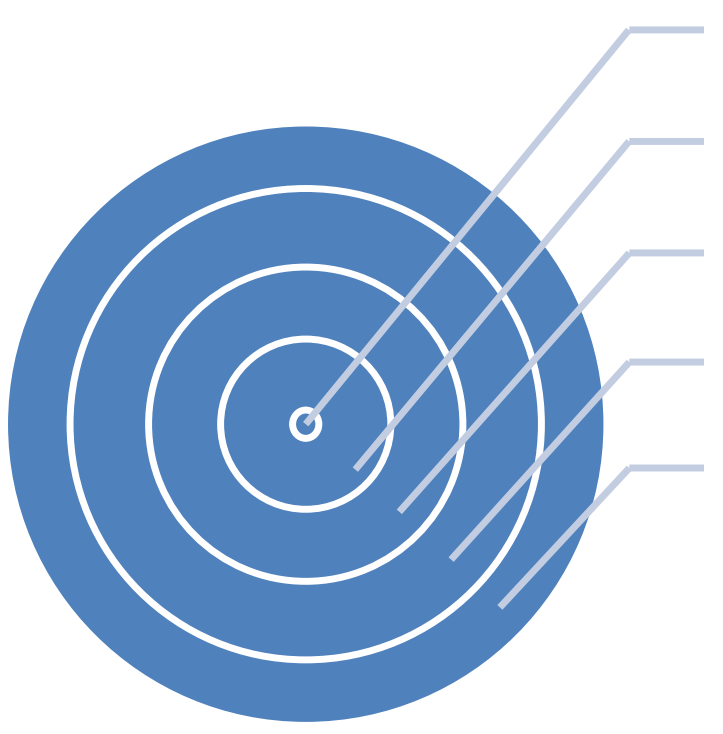

50ft. Buffer

400ft. Buffer

800ft. Buffer

1200ft. Buffer

1600ft. Buffer

Figure 2: The analyzed buffer distances are presented here. The study first examines the concentration of crime within a 50 foot buffer of transit nodes, followed by a 50-400 foot, 400-800 foot, 800-1200 foot, and 1200-1600 foot spatial buffer. The method allows for micro-level analysis of where crime events concentrate surrounding specific transit nodes within the Portland area. 


\section{Chapter 3: Results}

\section{Overview of Macro-Level Analysis Findings:}

The following sections examine whether burglary and robbery crimes concentrate near mass-transit nodes in Portland. This examination assesses the total crime count and percentage of all burglaries followed by robberies near mass-transit in Portland between May 2015 and August 2018 (see Table 1). These counts facilitate the calculation of LQ measures for each crime type. The findings of this macro level analysis provide the framework for further meso and micro-level analyses in the research study.

\begin{tabular}{|c|c|c|c|c|c|}
\hline$\frac{\text { Crime }}{\text { Type }}$ & $\begin{array}{l}\text { Total Area of } 400 \text { Foot } \\
\text { Buffers (Square Miles) }\end{array}$ & $\frac{\% \text { of the }}{\text { City Area }}$ & $\begin{array}{l}\text { Number of Events } \\
\text { (400 Foot Buffers) }\end{array}$ & $\frac{\% \text { of All }}{\text { Events }}$ & $\underline{L Q}$ \\
\hline Burglary & 1.9 & 1.3 & 741 & $5.5 \%$ & 4.1 \\
\hline Robbery & 1.9 & 1.3 & 591 & $19.2 \%$ & 14.7 \\
\hline
\end{tabular}

Table 1: Type of Crime by Area and Events with Location Quotient

\section{Do Burglary Crimes Concentrate Near Mass-Transit?}

There were 13,305 counts of burglary events reported to the Portland Police Bureau Crime Database between May 2015 and August 2018, and falling within the city limits. The events are considered according to their proximity to one of the 140 major transit stops within Portland. In total, 741 burglaries occurred within a 400 foot buffer of a transit node, equaling $5.4 \%$ of all events (see Table 1). The calculated LQs for the total burglary crimes near the transit nodes is 4.1 (see Table 1). As a result, the macro-level analysis finds burglary crime to exceed the threshold of 2.0, indicating considerable 
concentration. At 4.1, the LQ indicates that burglary crimes are 4.1 times more concentrated within close proximity to major transit nodes than the average rate of crime per area across Portland. Given these findings, this crime type will be subject to further meso- and micro-level analysis.

\section{Do Robbery Crimes Concentrate Near Mass-Transit?}

In order to compare the spatial patterns of two separate crime types, the same macro-level spatial analysis is conducted using the 3,068 robbery events reported to the Portland Police Bureau between May 2015 and August 2018. Of these events, 591 (19.2\%) occurred within a 400 foot buffer of a transit node (see Table 1). The calculated LQs for the total robbery crimes within a $400 \mathrm{ft}$. buffer resulted in a value of 14.7 (see Table 1). The LQs for robberies near mass-transit well exceeded the threshold of 2.0, which indicates there is a considerable concentration of robbery crime near mass-transit when compared to Portland. Specifically, robbery crimes are 14.7 times more concentrated near mass-transit nodes when compared with other areas of the city of Portland. The macro-level analysis found robbery crime exceeds the threshold in this research study, therefore, these robbery events and the specific transit nodes in Portland have been subject to meso and micro analyses in the most highly concentrated geographic areas.

Overview of Meso-Level Analysis Findings for Burglary:

Given the different types of stations grouped at the macro level (included Max Light Rail services and Portland Streetcar), the meso stage aims to identify whether the 
type of transit station impacts the concentration of burglary events. In total, there were 70 Max stations and 70 Portland Streetcar stops analyzed in the city limits of Portland. The total burglary crime count within the 400 foot buffers was 741 events, or 5.5 percent of all burglaries (see Table 2). When examining Table 2, the Max Light Rail and Portland Streetcar station totals for burglary count add up to 783 events, due to the overlap of 42 events occurring within 400 feet of both a Max stop and a streetcar stop, and are thus included in the total crime of both transit types.

\begin{tabular}{|c|c|c|c|c|c|}
\hline$\frac{\text { Transit }}{\underline{\text { Type }}}$ & $\frac{\underline{\text { Number of }}}{\underline{\text { Stations }}}$ & $\frac{\underline{\text { Total Burglary }}}{\frac{\text { Count (400 Foot }}{\text { Buffers) }}}$ & $\begin{array}{c}\frac{\text { Total \% of }}{\text { All }} \\
\text { Burglaries }\end{array}$ & $\frac{\underline{\text { Total \% of All }}}{\text { Burglaries Near }}$ & $\underline{\text { Transit }}$ \\
\hline $\begin{array}{c}\text { Max } \\
\text { Light } \\
\text { Rail }\end{array}$ & 70 & 284 & $2.1 \%$ & $36.7 \%$ & 2.8 \\
\hline $\begin{array}{c}\text { Portland } \\
\text { Streetcar }\end{array}$ & 70 & 489 & $3.7 \%$ & $63.3 \%$ & 5.9 \\
\hline Total & 140 & 741 & $5.5 \%$ & $100.0 \%$ & 4.1 \\
\hline
\end{tabular}

Table 2: Meso-Analysis of Burglary by Type of Transit Node

\section{Examining Max-Light Rail Transit Nodes:}

The examined 400-foot buffers surrounding each Max station equated to 30,322,089.3 square feet, or approximately 1.09 square miles; approximately 1.0 percent of the total geographic area of Portland. Of the total 13,305 burglary events, the count of burglaries within the examined Max Light Rail spatial buffers was 284. The Max Light Rail buffers contained approximately 2.1 percent of all burglaries across Portland, and 36.7 percent of all burglaries located near mass transit nodes (see Table 2). The calculated LQs for burglaries near Max-transit stops was 2.8, inferring burglary is 2.8 
times more concentrated near the Max Light Rail stops when compared to the spatial dispersion in Portland (see Table 2).

\section{Examining Portland Streetcar Transit Nodes:}

Reviewing the Portland Streetcar stations, there were a total of 70 examined transit stops comprised of 4 lines. The lines are the A loop, B loop, North South (NS) A and NS B lines. The total area of the 400 foot spatial buffers surrounding all of the stops was $25,101,591.5$ square feet or 0.9 square miles. The count of burglary crime within the buffers was 489 events or 3.7 percent of all burglaries in Portland (see Table 2). Approximately 63.3 percent of all burglary events occurring near a transit node concentrated near streetcar stops. The calculated LQ for Portland Streetcar stops was 5.9, indicating the occurrence of burglary near Portland Streetcar transit nodes was 5.9 times greater than the dispersion of burglaries in the Portland geographic area.

\section{Overview of Meso-Level Analysis for Robbery:}

Continuing the meso-level analysis from burglary to robbery crime, the types of stations categorized at the macro level are further explored to determine whether the type of transit impacts the concentration of robbery events. The following sections explore robbery, by examining the spatial-concentration of robbery events based on the type of station. 


\begin{tabular}{|c|c|c|c|c|c|}
\hline$\frac{\text { Transit }}{\underline{\text { Type }}}$ & $\begin{array}{c}\text { Number } \\
\text { of Stations }\end{array}$ & $\frac{\frac{\text { Total Robbery Crime }}{\text { Count (400 Foot }}}{\underline{\text { Buffers) }}}$ & $\begin{array}{c}\text { Total \% of } \\
\text { All Robberies }\end{array}$ & $\frac{\frac{\text { Total \% of All }}{\text { Robberies Near }}}{\text { Transit }}$ & $\underline{\mathbf{L Q}}$ \\
\hline $\begin{array}{c}\text { Max } \\
\text { Light } \\
\text { Rail }\end{array}$ & 70 & 382 & $12.4 \%$ & $61.2 \%$ & 16.6 \\
\hline $\begin{array}{l}\text { Portland } \\
\text { Streetcar }\end{array}$ & 70 & 241 & $7.8 \%$ & $38.8 \%$ & 12.7 \\
\hline Total & 140 & 591 & $19.2 \%$ & $100.0 \%$ & 14.7 \\
\hline
\end{tabular}

Table 3: Meso-Analysis of Robbery by Type of Transit Node

\section{Examining Max Light Rail Transit Nodes:}

Of the total 3,068 robbery events, 382, or 12.4 percent of all robberies in Portland occurred within the examined Max Light Rail spatial buffers (see Table 3). Of all robbery events occurring in proximity to transit lines, 61.2 percent occurred near a Max Light Rail station (see Table 3). The calculated LQ for robberies near a Max-transit station was 16.6, meaning robbery events were 16.6 times more concentrated near the Max Light Rail when compared to the spatial distribution of the crime in Portland (see Table 3).

\section{Examining Portland Streetcar Transit Nodes:}

When reviewing the Portland Streetcar nodes, the total count of robbery events within the 400 foot buffers was 242 crimes, or approximately 7.8 percent of all robberies (see Table 3). This equates to 38.8 percent of all robberies occurring near a major transit node. The calculated LQ for Portland Streetcar was 12.7, meaning the occurrence of robbery near Portland Streetcar was 12.7 times greater than the distribution of robberies in Portland. 


\section{Overview of Micro-Level Analysis Findings for Burglary Crime:}

At the micro-scale, the study investigates the five highest-crime transit nodes to explore how these events concentrate near these important locations. Table 4 reviews the micro-level analysis of the transit nodes with the highest concentrations of burglary crime. The list includes the following: NW Lovejoy and $13^{\text {th }}$ (Portland Streetcar North \& South) NW $10^{\text {th }}$ and Glisan (Portland Streetcar North and South A Loop), SW $11^{\text {th }}$ and Clay (Portland Streetcar North and South B Loop, SW 10 ${ }^{\text {th }}$ and Alder (Portland Streetcar North and South A Loop), and NW Northrup and $12^{\text {th }}$ (Portland Streetcar North and South). A breakdown of the total robbery count surrounding each station, as well as the percentage of robberies on the type of transit line, has been provided. In addition, Table 4 reviews the calculated LQs specific to the transit line, the percentage of all robberies and calculated LQs for each type of transit in relation to all robbery crime in Portland. For instance, the transit type, line and station with the highest concentration of robbery events was the Streetcar North and South Lovejoy and $13^{\text {th }}$ node. This transit node station is further broken down in the following section to outline the setup of Table 4.

In total, there were 41 events occurring within a 400 foot buffer of the Streetcar North and South Lovejoy and $13^{\text {th }}$ node (see Table 4). In relation to all burglary crime occuring near a Portland Streetcar node, 16.9 percent of the burglaries occurred near this specific station (see Table 4). The calculated LQ (Type of Transit) compares the concentration of burglary events near this specific transit node, in relationship to the concentration of burglary events near nodes on the same transit type. The value for the NW Lovejoy and $13^{\text {th }}$ transit node, in relationship to all analyzed Portland Streetcar 
transit stations, generated a statistic of 8.5 (see Table 4). This value indicates that burglary is 8.5 times more concentrated near this site, than compared with the density near all other Portland Streetcar transit nodes combined. While the count of burglary events occurring near the node totals just over $0 \%$ of all city burglaries, the LQ for the station demonstrates burglary crime is 5.8 times more concentrated in this locale than expected, given the average concentration across the city. The remaining 4 transit nodes generate similar statistics for each of the mentioned categories and are further presented in Table 4.

\begin{tabular}{|c|c|c|c|c|c|c|}
\hline$\frac{\text { Transit Type }}{\text { and Line }}$ & $\frac{\text { Name of }}{\underline{\text { Station }}}$ & $\frac{\text { Number of }}{\underline{\text { Events }}}$ & $\frac{\frac{\% \text { of Events }}{\text { On Transit }}}{\text { Type }}$ & $\begin{array}{c}\text { LQ } \\
\frac{\text { (Type of }}{\text { Transit) }} \\
\end{array}$ & $\frac{\% \text { of All }}{\text { Events }}$ & $\frac{\text { LQ of All }}{\underline{\text { Events }}}$ \\
\hline $\begin{array}{l}\text { Streetcar North } \\
\text { \& South }\end{array}$ & $\begin{array}{c}\text { NW } \\
\text { Lovejoy } \\
\text { and 13th }\end{array}$ & 41 & $16.9 \%$ & 8.5 & $0.0 \%$ & 5.8 \\
\hline $\begin{array}{l}\text { Streetcar North } \\
\text { \& South A } \\
\text { Loop }\end{array}$ & $\begin{array}{l}\text { NW } 10^{\text {th }} \\
\text { and Glisan }\end{array}$ & 31 & $12.8 \%$ & 6.4 & $0.0 \%$ & 4.4 \\
\hline $\begin{array}{l}\text { Streetcar North } \\
\& \text { South B } \\
\text { Loop }\end{array}$ & $\begin{array}{l}\text { SW } 11^{\text {th }} \\
\text { and Clay }\end{array}$ & 28 & $11.6 \%$ & 5.8 & $0.0 \%$ & 4.0 \\
\hline $\begin{array}{c}\text { Streetcar North } \\
\text { \& South A } \\
\text { Loop }\end{array}$ & $\begin{array}{l}\text { SW } 10^{\text {th }} \\
\text { and Alder }\end{array}$ & 26 & $10.7 \%$ & 5.4 & $0.0 \%$ & 3.7 \\
\hline $\begin{array}{l}\text { Streetcar North } \\
\quad \& \text { South }\end{array}$ & $\begin{array}{c}\text { NW } \\
\text { Northrup } \\
\text { and } 12^{\text {th }}\end{array}$ & 26 & $10.7 \%$ & 5.4 & $0.0 \%$ & 3.7 \\
\hline
\end{tabular}

Table 4: Micro-Analysis of Transit Nodes with Highest Concentration of Burglary Events

\section{Examining the Spatial Dispersion of Burglaries at Different Spatial Intervals:}

Further analysis follows Groff et al. (2012) and incorporates a series of buffers to identify how crime concentrates at the micro-level of analysis. Table 5 outlines the highest crime transit nodes as identified in Table 4, and searches within and beyond the original 400-foot buffer distance to examine the local-level crime concentration around 
each site. The results of Table 5 demonstrate micro-level variations between stations, illustrating that burglaries increase as distance from some high-crime stations increase and decrease as distance from other stations increase. These findings present an opportunity for specific intervention of community services at different distances from each of the mass-transit node areas; further addressed in the discussion section of this research study. The following sections provide a breakdown of the variation in the spatial dispersion of burglaries as the distance from stations increases for each of the highest crime transit nodes.

\begin{tabular}{|c|c|c|c|c|c|}
\hline Transit Node & $\underline{0-50 \mathrm{ft}}$. & $50-400 \mathrm{ft}$. & $\underline{400-800 \mathrm{ft}}$. & $800-1200 \mathrm{ft}$. & $1200-1600 \mathrm{ft}$. \\
\hline $\begin{array}{l}\text { NW Lovejoy } \\
\text { and 13th }\end{array}$ & 0 & 6.6 & 3.7 & 8.4 & 12.5 \\
\hline $\begin{array}{l}\mathrm{NW} 10^{\text {th }} \text { and } \\
\text { Glisan }\end{array}$ & 0 & 5.0 & 7.1 & 5.5 & 13.9 \\
\hline $\begin{array}{c}\mathrm{SW} 11^{\text {th }} \text { and } \\
\text { Clay }\end{array}$ & 0 & 4.5 & 4.7 & 8.2 & 4.3 \\
\hline $\begin{array}{l}\text { SW } 10^{\text {th }} \text { and } \\
\text { Alder }\end{array}$ & 0 & 4.2 & 4.0 & 6.0 & 9.9 \\
\hline $\begin{array}{l}\text { NW Northrup } \\
\text { and } 12 \text { th }\end{array}$ & 0 & 4.2 & 5.2 & 7.2 & 7.0 \\
\hline
\end{tabular}

Table 5: LQs by Transit Node and Buffer Area for Burglary Events

\section{O Foot to 50 Foot Buffer:}

Upon identifying the five stations with highest concentrations of burglary within 400 feet, the study explores within this distance to measure crime located at the station itself. The micro-level analysis draws further comparisons with the work of Groff and McCord (2012), who examined the spatial dispersion of crimes using a 0 to $50 \mathrm{ft}$. or 
0.009 square mile spatial buffer. Results displayed in Table 5 indicate that none of the top five transit nodes recorded a single event in the immediate 50 foot spatial buffer. When extending this analysis to all transit nodes (results not shown), the maximum count was five burglaries within 50 meters of a station, with the mean count of burglaries within 50 feet of a transit node being 0.3 . Overall, the majority of transit nodes did not experience a single burglary event within the 0 to 50 foot buffer.

\section{Foot to 400 Foot Buffer:}

The change from a 0 to 50 foot buffer, to a 50 to 400 foot buffer presents a considerable increase in burglary events. Specifically, the highest location quotient value among transit nodes was recorded at NW Lovejoy and $13^{\text {th }}$ (with a LQ value of 6.6), inferring that burglaries are 6.6 times more concentrated near this mass-transit station compared to all other areas in Portland. The other highest-crime transit nodes generated similar values with LQ values in the 4.0-5.0 range (see Table 5).

\section{Foot to 800 Foot Buffer:}

The increase in buffer distance to a range of 400 to 800 feet beyond the transit node generated mixed results regarding whether the concentration of crime increases or decreases at this distance. For instance, NW $10^{\text {th }}$ and Glisan increased from a LQ value of 5.0 (between 50 and 400 feet from the station), to a LQ value of 7.1 within a 400 to 800 foot buffer distance. NW Northrup and $12^{\text {th }}$ also displayed a smaller increase in concentration. However, NW Lovejoy and $13^{\text {th }}$ display a marked decreased in the concentration of crime, dropping from an LQ of 6.6, to an LQ of 3.7. SW $11^{\text {th }}$ and Clay, 
and SW $10^{\text {th }}$ and Alder both generated a similar LQ value to the previous buffer distance, inferring that as the spatial area changes, the transit node maintained a constant concentration of burglary offenses.

\section{Foot to 1200 Foot Buffer:}

The area change from a 400-800 foot to 800-1200 foot found the concentration of burglaries to increase at 4 of the 5 ranked transit nodes. NW Lovejoy and $13^{\text {th }}$, SW $11^{\text {th }}$ and Clay, SW $10^{\text {th }}$ and Alder, and NW Northrup and $12^{\text {th }}$ increased in the concentration of burglary events after increasing the spatial area by an additional 400 foot buffer surrounding the nodes. The only transit node decreasing in the concentration of events was NW $10^{\text {th }}$ and Glisan, where concentrations dropped from an LQ of 7.1, to 5.5.

\section{Foot to 1600 Foot Buffer:}

The final spatial change also generated inconsistent findings concerning whether burglaries increase, decrease, or remain constant as the spatial area changes. NW Lovejoy and $13^{\text {th }}$, NW $10^{\text {th }}$ and Glisan and SW $10^{\text {th }}$ and Alder indicated a considerable increase in concentrations of burglaries between 1200 and 1600 feet from the station, while SW $11^{\text {th }}$ and Clay showed a considerably decreased concentration of burglary events. NW Northrup and $12^{\text {th }}$ was found to change minimally by a reduced concentration value of 0.2 . 


\section{Overview of Micro-Level Analysis Findings for Robbery Crime:}

At the micro-scale, the study also examined the five transit nodes reporting the highest concentration of robbery events, in order to explore how such events concentrate near mass transit nodes in Portland. Table 6 shows the micro-level analysis of transit nodes with the highest concentrations of robbery in Portland. The list includes the following: Union Station \& NW 6th and Hoyt (Green Yellow Max), Pioneer Courthouse $\&$ SW $6^{\text {th }}$ (Blue Green Red Max), Lloyd Center $\&$ NE $11^{\text {th }}$ Ave (Blue Green Red Max), Skidmore Fountain (Blue Red Max), and Art Museum (Portland Streetcar North \& South A Loop). Each station is listed according to the type of transit, including the line name. A breakdown of the total robbery count surrounding each station as well as the percentage of robberies on the type of transit line has been provided. In addition, Table 6 shows the calculated LQs specific to the transit type, the percentage of all robberies and calculated LQs for each type of transit in relation to all robbery crime in Portland. For instance, the transit type, line and station with the highest concentration of robbery events was the Green/Yellow Max, Union Station \& NW $6^{\text {th }}$ and Hoyt node. In total, there were 44 robbery events occuring within a 400 foot buffer of the transit node (see Table 6). The following section further describes this station in reference to Table 6.

In relationship to all robbery crime occurring within a 400 foot buffer of the Trimet nodes, 11.5 percent of robberies occurred at the Green/Yellow Max, Union Station \& NW $6^{\text {th }}$ and Hoyt node (see Table 6). The calculated LQ value for this transit node in relationship to all analyzed Max transit station generated a value of 1.7 (see Table 6). The value infers the concentration of robbery is 1.7 times more concentrated at this 
station, than the dispersion of robbery events near all Max transit nodes in Portland. In relation to the total robbery events in the city of Portland, 1.4 percent of these crimes occurred at this station (see Table 6). The calculated LQ examining the spatial concentration of robberies at this station in comparison to the dispersion of these events in the greater Portland area generated a LQ value of 27.7 (see Table 6). This value infers that robbery crime is 27.7 times more concentrated than the geographic dispersion of these events in Portland. The remaining four transit nodes generate similar statistics for each of the mentioned categories and are further presented in Table 6.

\begin{tabular}{|c|c|c|c|c|c|c|}
\hline $\begin{array}{c}\text { Transit Type } \\
\text { and Line }\end{array}$ & $\frac{\underline{\text { Name of }}}{\text { Station }}$ & $\frac{\text { Number of }}{\text { Events }}$ & $\frac{\frac{\text { \% of Events }}{\text { On Transit }}}{\text { Type }}$ & $\begin{array}{c}\frac{\text { LQ }}{\text { (Type of }} \\
\text { Transit) }\end{array}$ & $\frac{\text { \% of All }}{\text { Events }}$ & $\frac{\underline{\text { LO of All }}}{\underline{\text { Events }}}$ \\
\hline $\begin{array}{c}\text { Green Yellow } \\
\text { Max }\end{array}$ & $\begin{array}{c}\text { Union } \\
\text { Station \& } \\
\text { NW 6th } \\
\text { and Hoyt }\end{array}$ & 44 & $11.5 \%$ & 1.7 & $1.4 \%$ & 27.7 \\
\hline $\begin{array}{c}\text { Blue Green } \\
\text { Red Max }\end{array}$ & $\begin{array}{c}\text { Pioneer } \\
\text { Courthouse } \\
\text { \& SW 6th }\end{array}$ & 40 & $10.5 \%$ & 1.5 & $1.3 \%$ & 25.2 \\
\hline $\begin{array}{c}\text { Blue Green } \\
\text { Red Max }\end{array}$ & $\begin{array}{c}\text { Lloyd } \\
\text { Center \& } \\
\text { NE 11th } \\
\text { Ave }\end{array}$ & 34 & $8.9 \%$ & 1.3 & $1.1 \%$ & 21.4 \\
\hline Blue Red Max & $\begin{array}{c}\text { Skidmore } \\
\text { Fountain }\end{array}$ & 32 & $8.4 \%$ & 1.2 & $1.0 \%$ & 20.2 \\
\hline $\begin{array}{c}\text { Streetcar } \\
\text { North \& South } \\
\text { A Loop }\end{array}$ & $\begin{array}{c}\text { Art } \\
\text { Museum }\end{array}$ & 28 & $7.3 \%$ & 1.1 & $0.9 \%$ & 17.7 \\
\hline
\end{tabular}

Table 6: Micro Analysis of Transit Nodes with Highest Concentration of Robbery Events

\section{Examining the Spatial Dispersion of Robberies at Different Spatial-Intervals:}

With an understanding of which stations have the highest concentration of robbery crime, the next phase of this micro-level analysis explores the concentration of robbery events at these stations at a variety of distances from the nodes, themselves. 
Table 7 describes each of the transit nodes listed in Table 7 with calculated LQs following the different spatial buffers examined by the literature. The results of Table 7 demonstrate variation in micro-spatial concentrations according to each high-crime station. The following sections provide a breakdown of the variation in the spatialdispersion of robberies as the spatial area increases for each of the ranked transit nodes.

\begin{tabular}{|c|c|c|c|c|c|}
\hline Transit Node & $\underline{0-50 \mathrm{ft}}$. & $50-400 \mathrm{ft}$. & $400-800 \mathrm{ft}$. & $800-1200 \mathrm{ft}$. & $1200-1600 \mathrm{ft}$. \\
\hline $\begin{array}{c}\text { Union Station \& } \\
\text { NW } 6^{\text {th }} \text { and } \\
\text { Hoyt }\end{array}$ & 73.6 & 20.1 & 14.5 & 14.5 & 34.7 \\
\hline $\begin{array}{c}\text { Pioneer } \\
\text { Courthouse \& } \\
\text { SW } 6^{\text {th }} \text { Ave. }\end{array}$ & 5.3 & 27.9 & 34.1 & 39.1 & 31.5 \\
\hline $\begin{array}{l}\text { Lloyd Center } \\
\text { and NE } 11^{\text {th }} \\
\text { Ave. }\end{array}$ & 141.9 & 31.5 & 37.2 & 8.8 & 8.8 \\
\hline $\begin{array}{l}\text { Skidmore } \\
\text { Fountain }\end{array}$ & 5.3 & 162.9 & 16.4 & 24.0 & 33.4 \\
\hline Art Museum & 10.5 & 136.6 & 6.3 & 17.0 & 31.5 \\
\hline
\end{tabular}

Table 7: LQs by Transit Node and Buffer Area for Robbery Events

\section{Foot to 50 Foot Buffer:}

Table 7 reviews each of the transit nodes with the highest concentrations of robbery within the initial 400 foot analyzed buffer. Results indicate considerable concentrations of robbery crime near Union Station \& NW $6^{\text {th }}$ and Hoyt (with a reported LQ value of 73.6), and Lloyd Center and NE $11^{\text {th }}$ Ave (LQ value of 141.9). The values indicate both stations have very high concentrations of robberies within a 50 foot spatial buffer surrounding the transit station. The count of robberies within a 50 foot area surrounding Union Station and NW $6^{\text {th }}$ and Hoyt is approximately 73.6 times more concentrated compared to the spatial dispersion of robberies in Portland. The count of 
robberies within a 50 foot spatial area of the Lloyd Center and NE $11^{\text {th }}$ Ave is approximately 141.9 times more concentrated than the spatial dispersion of robberies in Portland. The remaining top-five stations each report lower LQ values that still exceed the 2.0 threshold, indicating that these stations also contain considerably more robberies within this area than other spaces within Portland as a whole. For instance, Pioneer Courthouse and SW $6^{\text {th }}$ Avenue, and Skidmore Fountain only had one crime count each within a 50 foot area of the transit nodes. These stations exceeded the threshold for micro-analysis with a LQ value greater than 2.0. Robberies are 5.3 times more concentrated at these stations when compared to the spatial dispersion of the crime in Portland. The Art Museum had two crime events within a 50 foot buffer, resulting in a LQs value of 10.5, therefore, robberies near the Art Museum transit node are 10.5 times more concentrated than the spatial-dispersion of the crime within Portland.

\section{Foot to 400 Foot Buffer:}

When examining the 50 to 400 foot buffer interval, there was considerable variation within each of the high crime transit nodes events. For example, the Union Station \& NW $6^{\text {th }}$ and Hoyt transit station decreased from an LQ of 20.1 at the 0 to 50 foot buffer to a LQ value of 14.5 within a 50 to 400 buffer. The Lloyd Center and NE $11^{\text {th }}$ Ave node followed a similar pattern in decreasing in the spatial concentration of robbery crime at this level of analysis. The remaining three transit nodes, Skidmore Foundation, Pioneer Courthouse and the Art Museum increased in the count of robbery events from a 0 to 50 foot buffer to a 50 foot to 400 foot buffer. 


\section{Foot to 800 Foot Buffer:}

When the buffer expanded from 400 feet to 800 feet, the LQ value decreased for Union Station and NW $6^{\text {th }}$ and Hoyt, Skidmore Fountain and the Art Museum. Union Station and NW $6^{\text {th }}$ and Hoyt decreased from a LQ value of 20.1 to 14.5 ; indicating the concentration of robberies decreased as the spatial area increased away from the transit node. While, the Lloyd Center and NE $11^{\text {th }}$ Ave transit stop experienced an increase with a location quotient change from 31.5 to 37.2 and Pioneer Courthouse from a LQ value of 27.9 to 34.1 ; indicating the concentration of robberies increased as the spatial area increased away from these transit nodes.

\section{Foot to 1200 Foot Buffer:}

When considering the 800 to 1200 foot buffer interval, there was also variation in concentrations among each of the transit nodes. For instance, Union Station \& NW $6^{\text {th }}$ and Hoyt maintained a consistent crime count and LQ value of 14.5. However, Pioneer Courthouse \& SW $6^{\text {th }}$ Ave, Skidmore Fountain and the Art Museum transit nodes showed an increase in the concentration of robberies within the buffer area. The only transit node experiencing a decreased concentration of events was the Lloyd Center and NE $11^{\text {th }}$ Ave, which dropped considerably from a LQ value of 37.2 at 400 to 800 feet, to a LQ value of 8.8 within the buffer distance of 800 to 1200 feet from the station.

\section{Foot to 1600 Foot Buffer:}

When examining the 800 to 1200 foot buffer to $1200-1600$ foot buffer, further variation exists between each of the top five transit nodes. For example, the Union 
Station $\&$ NW $6^{\text {th }}$ and Hoyt, Skidmore Fountain and Art Museum stations experienced a dramatic increase in the spatial concentration of robberies. In contrast, the Lloyd Center and NE $11^{\text {th }}$ Ave transit node remained constant after the buffer change with a calculated LQ value of 8.8. The only transit node that experienced a decrease in the amount of robbery events was Pioneer Courthouse and SW $6^{\text {th }}$ Ave, which decreased from an LQ of 39.1 to an LQ of 31.5 at the 1200 to 1600 foot distance. 


\section{Chapter 4: Discussion and Future Directions}

The objective of the study is to add the conversation in the literature surrounding the relationship between mass-transit, and the concentration of burglary and robbery crimes. Empirical studies by Sherman et al. (1989), Loukaitou-Sideris et al. (2002), Kooi (2003), and Hart and Miethe (2014) have found crime to concentrate near masstransportation and other activity nodes. More recent literature such as Gallison (2016), Gallison and Andresen (2017), Ridgeway and MacDonald (2017), however, did not support the findings.

The current research adds to the conversation in the literature by exploring crime patterns near mass-transit at the macro, meso and micro levels of analysis within Portland. The impact of the research adds to local knowledge about crime patterns near transit, finding that burglary and robbery events are more concentrated near mass-transit nodes elsewhere in the city. Burglary crime was found to concentrate near mass-transit nodes at a rate that was approximately 4.2 times more than the average concentration of crime per area in Portland as a whole. By comparison, robbery crime was found to concentrate near mass-transit nodes at a rate 14.7 times higher than elsewhere in the city. The difference in concentration near mass-transit nodes for each of the crime types has opened the door for further exploration at different spatial levels of analysis. As a result, this study drew comparisons between different categories of transportation node, and further explored the areas surrounding specific transit stations reporting disproportionately high concentrations of these offenses. Results from the study may serve to aid in improved resource allocation, while increasing public understanding about 
how crime concentrates near major transit nodes in Portland. Beyond this locale, the study furthers understanding about the importance of considering transit node type, and crime type, when exploring the inter-relationships between transit and crime.

\section{Recommendation from Literature for Conducting of a Macro-Level Analysis:}

In determining whether transit impacts urban crime patters, previous studies have conducted a variety of analyses in densely populated areas throughout the United States such as Chicago, New York, Los Angeles and Washington D.C. The examinations have frequently called for further replication to further analyze the accuracy and applicability of the findings across a variety of study areas. Most recently, Ridgeway and Macdonald (2017) studied Los Angeles rail stations and crime events reported to the Los Angeles Police Department from 1988 to 2014. Their findings indicate rail transportation may generate no major overall consequence for patterns of crime at the neighborhood level. The study calls for future research to examine other cities at a micro-level of analysis.

The completion of the current research study in Portland aims to respond to the call for further investigation. The study finds burglary and robbery events concentrate near transit nodes at rates exceeding two times that of other areas within the city. The findings set more opportunities for further analysis. Concentrations of crime near transit nodes may be, in part, due to the confluence of opportunities at these locations, including a higher number of targets brought to the locales by the transit nodes themselves. Further, this may be associated with nearby businesses and establishments, accessible via the transit nodes. While both burglary and robbery offenses were concentrated at and near transit nodes, robbery events in these spaces occurred at considerably higher rates than 
did burglary. The findings are reflective of what would be suggested by environmental criminology theory, as the influx of people around these spaces may increase, the presence of, both opportunities and motivated offenders for robbery events, while increasing access may facilitate burglary events nearby the locations. A common theme in the literature discussed how transportation can frame opportunities for crime within the surrounding community due to an influx of people and an associated increase in opportunity (Louikatiou-Sideris, 1999; Brantingham et al., 1991). Further studies should explore the surrounding environment and land use characteristics located in close proximity to transit nodes.

\section{Meso-Level Findings:}

When comparing different activity and transit nodes, it is important to note how each may differently relate to crime in the nearby urban environment. Many locations bring together a large number of people in a small geographic area when compared with the relative spatial dispersion across an urban city. With an increased influx of people situated around an activity node and examined spatial area, Groff and McCord (2012) have found areas with an LQ value exceeding the 2.0 threshold had a higher probability of promoting the observed occurrences of crime within the studied environment. Criminologists such as Loukaitou-Sideris (1999) and Brantingham et al. (1991) argued that public transportation frames opportunities for criminal acts due to moving a large proportion of a high-risk population around the community with a restricted number of destinations and paths. Ultimately, establishments located near mass-transportation stations and routes may be at higher risk of burglary and robbery crime. Clustering and 
patterning of the concentrations was found to be substantially influenced by how and why people travel and move in a city. Andresen (2016) states "there will be concentrations of overlapping activity nodes and within those nodes, some situations that become crime generators and some that are crime attractors" (Brantingham et al., 1991; Andresen, 2016, 112).

This research examines two types of mass-transit nodes in Portland which move the community of Portland, daily around the built environment. The transit nodes included Max Light Rail and Portland Streetcar stations, totaling 140 stations. The task of identifying specific types of transit in need of resources and intervention can be a challenging task for stakeholders and executives administering the operation of these services. At the meso-level, this research identifies Max Light Rail as experiencing the highest concentration of robbery crimes, compared with Portland Streetcar services. The level of concentration was dispersed throughout the Max stops, as there was minimal variation between the ranked transit nodes found to have the highest concentration of events. The ranked transit nodes generated LQ values in the 1.0 to 2.0 range, suggesting the nodes experiencing the highest concentration of events were similar if not slightly above the average concentration of crime near all Max stops. Portland Streetcar stops also exceeded the 2.0 threshold, and experienced a high concentration of robbery events near the analyzed transit nodes. In relationship to burglary crimes, Portland Streetcar had the highest count and LQ value for burglary events, followed by Max-Light Rail, indicating that Streetcar stops may be more important when analyzing burglary events. Further studies must explore the land use mixes surrounding each type of transit node to further understand these findings. These findings continue the conversation in the examination of 
how different types of transit impact may impact crime and how the type of crime may concentrate differently around transit.

Going forward, I look to supplement this analysis by examining ridership data provided by Trimet and the Oregon Department of Public Transportation, as well as transit line data to pinpoint robbery concentrations at each transit type. In addition, I would consider using the approach of Loukaitou-Sideris et al. (2002) and the analysis of the Green Line Transit which extend into several counties in Los Angeles. This approach was also modeled by Clark and Belanger (1996) in mapping the New York subway system and analyzing the distribution of crime at different nodes. I would also consider the extension of Portland Trimet services outside of Portland city limits, such as in Washington County, where an additional 40 Trimet stops and the WES Commuter rail extend into Milwaukee, Tualatin, Tigard and Beaverton. By examining the full transportation route of Max light rail services, this study could explore the potential comparison between how crime is concentrated near mass-transit within Portland city limits in relationship to other locales while analyzing the same transit type. For example, this study would be able to compare the percentage of a total crime type occuring at a specific Max station, with all Max stations throughout the Portland and the surrounding environments. Furthermore, I draw comparisons to other types of transit, such as Portland Streetcar, where 40 other Max stations would be included in the calculation of the total buffer area, counts of crime and LQ values. This would require an extension of this study with reliable data from each of the areas. 


\section{Micro-Level Findings:}

Similar to the work of Groff and McCord (2012) and McCord and Ratcliffe (2007), this study conducted a micro-level analysis to identify where robbery crimes are most highly concentrated and at what spatial area of analysis. In relation to the literature, the use of LQs to determine the concentration of crime near mass-transit and other activity nodes revealed different empirical findings. McCord and Ratcliffe (2007), examined the micro-level spatial analysis of drug markets in Philadelphia, Pennsylvania. Using a 400 foot spatial buffer, McCord and Ratcliffe calculated a LQs value identifying drug arrests as being clustered within 400 feet of subway stations. Similar to the methodology of McCord and Ratcliffe (2007), Groff and McCord (2012) examined the role of parks as crime generators at the neighborhood level. Their LQs revealed the concentration of property, violent and disorder crime to be more clustered around, and in, parks.

Unlike Groff and McCord, however, I did not find similar patterns in the increase or decrease of burglary or robbery crime with different spatial areas. I found inconsistent results in regard to whether robberies or burglaries increased or decreased as the buffer extended into the surrounding environment. Despite inconsistent findings, I determined where the highest concentrations of robberies and burglaries fell in relationship to the distance from the transit node being explored. For example, I found a high concentration of robbery events within a 50 foot spatial area of the Lloyd Center \& NE $11^{\text {th }}$ Ave and Union Station \& NW $6^{\text {th }}$ and Hoyt transit nodes. Whereas, other transit nodes such as the Art Museum and Skidmore Fountain were found to have increased concentrations of 
robbery further away from the transit stop and into the immediate environment. In addition, I considered the accuracy and efficiency of the buffer areas for the specific types of crime. For example, the smaller buffer areas such as the 0 to 50 foot and 50 to 400 foot ranges showed high concentrations of robbery counted. For the crime type of burglary, however, there were no crime counts that occurred within a 0 to 50 foot buffer. This may be in part due to the limited opportunity for burglary events within the environment. Therefore, the 50 to 400 foot measurement was a more effective method of measuring the spatial concentration of this crime type near the analyzed transit nodes. The findings and the reflection on the methodology are important for understanding the best methodological approach to measuring the concentration of robbery and burglary based on the type of crime for resource allocation and intervention in determining where these events are being reported and committed with opportunities for CPTED and Situational Crime Prevention with the identified area at the micro-level of analysis.

\section{Limitations:}

In advancing the work of the empirical study, special regard should be given to the use of secondary data, overlapping of spatial buffers and inflation of crime counts, and the timeframe of available data collection. The use of secondary data from a public service database (Portland Police Bureau, 2018), does not allow for the fine-coded spatial-analysis of crime events within a densely populated urban area recommended by Ridgeway and Macdonald (2017). The data source used therein incorporates longitude and latitude coordinates for each burglary and robbery offense, though, the point data was aggregated to the street block or intersection level to protect the identity and location of 
victims associated with the crimes. As a result, the smaller micro-level findings may be impacted by the method of data reporting. Specific to Portland, the examination of specific addresses for crime events requires an MOU agreement between the public service agency recording the data (e.g., Portland Police Bureau) and the researcher or partnering institution examining the material. Due to the timeline of this project, an MOU agreement was unable to be incorporated into the research. If the researcher had an extended timeframe to conduct a similar project, it is recommended an agreement between the database service and the researcher be incorporated to fully analyze the spatial-concentration of crime within specific geographic locations.

Another consideration in examining the spatial concentration and dispersion of crime at different spatial-levels concerns the use of reported crime data in a research study. When using reported crime data, especially to a public service agency, such as a police department, the data may not be representative of all crime events occurring from a geographic context. Without an account for all crime events, whether reported or unreported, the study is only able to recommend specific interventions and target hardening for types of transit and specific stations which are represented with the available secondary data. The limitation also speaks to the ability to evaluate 3-years of data as provided by the Portland Police Bureau between May 2015 to August 2018. Due to missing data prior to May 2015, the study was unable to fully address data from 2015 and potentially, previous years for the temporal component.

When considering the generalization of the empirical study, the research provides recommendations specific to recent robbery and burglary crime, as well as the 140 analyzed transit nodes in Portland. In addition, the study adds to the conversation in the 
literature, regarding the concentration of crime near mass transit in a densely populated urban area that has not been previously examined. I recommend for research in other densely populated urban areas to continue the empirical conversation and to further address the discourse in the empirical literature with a continuation and analysis of the utility of the methodologies with presented findings, interpretations and recommendations for further empirical research at the macro-, meso- and micro-level of analyses.

\section{Recommendation for Future Research:}

Previous research studies have either examined crime from a macro-, meso- or micro-perspective without systematically following the methodologies to identify full concentrations of crime in a geographic area. Without this level of in-depth analysis, it may be concluded crime does not concentrate at a specific unit of analysis, therefore, lead to a lack of resources, funding and attention to transit crime impacting the environment at the macro-, meso- and micro-unit of analyses. This is especially important when considering the impact mass-transit may have at the city, neighborhood and immediate environment surrounding transit nodes. Similar to other activity nodes, transit can act as a crime generator and potentially, attractors in which a large quantity of people congregate by accessing and getting off of these transportation routes. Furthermore, transit stops may develop opportunities and a reputation for committing criminal acts without a level of deterrence observed at more manageable establishments such as parking facilities, malls, and restaurants. Surrounding businesses which may not be within the literature's spatially-examined vicinity of mass-transit may still be at increased risk of potential 
victimization, as observed in the mapping of commercial establishments and the heightened crime densities immediately surrounding these buildings.

When considering the concentration of robbery and robbery within a geographic area, it is necessary to fully evaluate the dispersion of recorded crime in the environment. From the macro perspective, robbery crime demonstrated a high concentration in specific Portland neighborhoods. Burglary events on the other hand, were scattered throughout Portland city limits with less concentration that was modeled in the LQ calculations. The findings indicate that crime concentrates around transit, but concentrates differently, so it is important to not aggregate crime types, in order to fully understand the impact of this type of land use. To achieve the optimal implementation of policy and resources, further analysis is necessary at the meso- and micro- levels within these districts. At the mesolevel, this study found the type of transit matters, as crime concentrated differently around each type of transit. At the micro-level, the analysis was of critical importance as it indicated variation from node to node and that some stations have higher crime than others.

\section{Conclusion}

The goal of the research study was to continue the conversation of the literature in assessing how robbery and burglary crimes are concentrated near mass-transit in a highly concentrated geographic area. To answer this question, I conducted a quantitative analysis at the macro, meso and micro level of analysis to explore the concentration and clustering of crime near mass-transit nodes, specific types of transit and stations in Portland. The study found robbery to be highly concentrated near mass-transit nodes. 
Burglary events near mass-transit were less concentrated, but still met the threshold of concentration to conduct further meso- and micro-level analyses. As a result, the study examined the specific concentration of robbery and burglary offenses near different types of mass-transit and found Trimet services had the highest concentrations of robbery and Portland Streetcar to have the highest concentrations of burglary. At the micro-level of analysis, the study found inconsistent findings regarding whether robbery and burglary crime increased or decreased as the spatial area increased/expanded into the surrounding environment away from the transit station. Despite these inconsistencies, I was able to provide a complete spatial-analysis of the dispersion and clustering of robbery and burglary crime for each of the transit nodes identified as having the highest concentrations of robbery in Portland city limits. By providing this level of in-depth analysis, the research serves as a resource to local public safety agencies such as the Portland Police Bureau for specific intervention and resource allocation in addressing the disproportionate concentration of these offenses. I recommend future research continue to add the conversation regarding whether crime concentrates near mass transit, with the recommendation of analyzing non-aggregated crime data, a more extensive data collection timeline, and a complete analysis of the transit line extending into different geographic areas. 


\section{References}

Altstadt, R. (2018, May 23). TriMet continues to grow safety and security as 2017 reported offenses on, near transit system released. Retrieved October 18, 2018, from http://news.trimet.org/2018/05/trimet-continues-to-grow-safety-and-security-as-2017reported-offenses-on-near-transit-system-released/

Bernasco, W., \& Block, R. (2011). Robberies in Chicago: A block-level analysis of the influence of crime generators, crime attractors, and offender anchor points. Journal of Research in Crime and Delinquency, 48 (1), 33-57

Block, R., \& Davis, S. (1996). The environs of rapid transit stations: A focus for street crime or just another risky place. Crime prevention studies, 6, 237-57.

Brantingham, P.L. and Brantingham, P.J. (1995) Criminality of place: Crime generators and crime attractors. European Journal on Criminal Policy and Research 3 (3), 1-26.

Brantingham, P. L., \& Brantingham, P. J. (1998). Mapping crime for analytic purposes: location quotients, counts and rates. Crime mapping and crime prevention, 8, 263-288.

Brantingham, P. J., Brantingham, P. L., \& Andresen, M. A. (2016). The geometry of crime and crime pattern theory. Environmental criminology and crime analysis, 98-115.

Brantingham, P. L., Brantingham, P. J., Vajihollahi, M., \& Wuschke, K. (2009). Crime analysis at multiple scales of aggregation: A topological approach. In Putting crime in its place (pp. 87-107). Springer, New York, NY.

Clarke, R. V., Belanger, M., \& Eastman, J. (1996). Where angels fear to tread: A test in the New York City subway of the robbery/density hypothesis. Preventing Mass Transit Crime: Crime Prevention Studies, 6, 217-236.

Cole, S. (2007). The Regional Science of Tourism: An Overview. Journal of Regional Analysis \& Policy, 37(3), 183-92.

DeGeneste H, Sullivan J: Policing Transportation Systems. Springfield, Illinois: Charles C. Thomas Inc; 1994.

Dumont, T. (2018, August 30). Despite rise in offenses, TriMet leaders confident in safety.

Retrieved October 18, 2018, from https://www.kptv.com/news/despite-rise-in-offenses-trimetleaders-confident-in-safety/article_613943c1-3ff5-55cb-8163-012d7aa15c5d.html

Frank, R., Dabbaghian, V., Reid, A., Singh, S., Cinnamon, J., \& Brantingham, P. (2011). Powerof criminal attractors: modeling the pull of activity nodes. Journal of Artificial Societies and Social Simulation, 14(1), 6.

Gallison, J. K. (2016). The line of crime: Dismantling fears and concerns of crime along Vancouver SkyTrain's Canada Line. Security Journal, 29(3), 485-500. 
Gallison, J. K., \& Andresen, M. A. (2017). Crime and public transportation: a case study of Ottawa's O-Train system. Canadian Journal of Criminology and Criminal Justice, 59(1), 94-122.

Groff, E. (2011). Exploring 'near': Characterizing the spatial extent of drinking place influence on crime. Australian \& New Zealand Journal of Criminology, 44(2), 156179. https://doi.org/10.1177/0004865811405253

Groff, E., \& McCord, E. S. (2012). The role of neighborhood parks as crime generators. Security journal, 25(1), 1-24.

Hart, T. C., \& Miethe, T. D. (2014). Street robbery and public bus stops: a case study of activity nodes and situational risk. Security Journal, 27(2), 180-193.

Kinney, J. B., Brantingham, P. L., Wuschke, K., Kirk, M. G., \& Brantingham, P. J. (2008). Crime attractors, generators and detractors: Land use and urban crime opportunities. Built environment, 34(1), 62-74.

Kooi, B. R. (2013). Assessing the correlation between bus stop densities and residential crime typologies.Crime prevention and community safety, 15(2), 81-105.

La Vigne, N. G. (1996). Safe transport: Security by design on the Washington metro. Preventing mass transit crime, 6, 163-197.

Loukaitou-Sideris, A., Liggett, R., \& Iseki, H. (2002). The geography of transit crime: Documentation and evaluation of crime incidence on and around the green line stations in Los Angeles. Journal of Planning Education and Research, 22(2), 135-151.

Loukaitou-Sideris, A. (1999). Hot spots of bus stop crime: The importance of environmental attributes. Journal of the American Planning association, 65(4), 395-411.

McCord, E. S., \& Ratcliffe, J. H. (2007). A micro-spatial analysis of the demographic and criminogenic environment of drug markets in Philadelphia. Australian \& New Zealand Journal of Criminology, 40(1), 43-63. Monthly Neighborhood Offense Statistics [Advertisement]. (2017, October 07).Retrieved January 25, 2018, from https://www.portlandoregon.gov/police/71978 Strategic Services Division, Portland Police Bureau.

Newton, A. D., Partridge, H., \& Gill, A. (2014). Above and below: measuring crime risk in and around underground mass transit systems. Crime Science, 3(1), 1.

Njus, E. (2017, July 26). Crime flat on TriMet, agency says, but data lacking. Retrieved October 18, 2018, from https://www.oregonlive.com/commuting/index.ssf/2017/07/crime _flat_on_trimet_agency_sa.html

Portland Police Bureau Crime Definitions. (2019). Retrieved April 15th, 2019 from https://www.portlandoregon.gov/police/article/573676

Portland Police Bureau Crime Database. (2018). Retrieved September 1st, 2018 from https://www.portlandoregon.gov/police/71978 
Redden, J. (2017, October 05). TriMet: Ridership down because riders changing. Portland Tribune. Retrieved October 18, 2018, from https://portlandtribune.com/pt/9news/374304-258557-trimet-ridership-down-because-riders-changing

Richards LG, Hoel LA: Planning Procedures for Improving Transit Station Security. Washington, DC: U.S. Department of Transportation; 1980.

Ridgeway, G., \& MacDonald, J. (2017). Effect of Rail Transit on Crime: A Study of Los Angeles from 1988 to 2014. Journal Of Quantitative Criminology, 33(2), 277-291. doi:10.1007/s10940-016-9296-7.

Schlossberg, M., Dill, J., Ma, L., \& Meyer, C. (2013). Measuring the performance of transit relative to livability.

Sedelmaier C: Railroaded: The Effects of a New Public Transport System upon Local Crime Patterns: Unpublished PhD Thesis. New Jersey: Rutgers University; 2003.

Sherman, L. W., Gartin, P. R., \& Buerger, M. E. (1989). Hot spots of predatory crime: Routine Activities and the criminology of place. Criminology, 27(1), 27-56.

Smith, M. J., \& Clarke, R. V. (2000). Crime and public transport. Crime and Justice, 27, 169233.

Trimet Annual Report: An Update For Our Riders And The Community (Rep.). (2018). Retrieved October 18, 2018, from Trimet website:https://trimet.org/annualreport/trimet-annualreport-2018.pdf

Trimet Ridership and Performance Statistics: Monthly Performance Data, Ridership Trends and Rider Characteristics. (2018). Retrieved October 18, 2018, from https://rimet.org/about/performance.htm.

Vu Y: Bus Stops and Crime: Do Bus Stops Increase Crime Opportunities in Local Neighbourhoods? Unpublished PhD Thesis. New Jersey: Rutgers University; 2009.

Wuschke, K., \& Kinney, J. B. (2018). Built Environment, Land Use, and Crime. The Oxford Handbook of Environmental Criminology, 475. 